countries with a normally lower consumption. The importance of a quick supply of fertilizers as an essential to a recovery of agriculture was streseed, and Mr. Nemec uttered a warning with regard to the timker and paper position. Requirements in respect of leather, skins and boots over the same six-month period have been calculated on the consumption under the British rationirg scheme of 1941-42, and the British ration also forms the agreed basis in respect of imports of textiles. Careful attention has also keen given in the plan to the consumption of crude oil and its by-products and of coal. Czechoslovakia expects to be once more in a position to export coal, of which Austria was formerly her kest customer. Requirements of the non-ferrous metals, copper, lead and zinc will be great, and supplies of medicants, seeds, certain machinery such as locomotives and lorries, will te of primary importance.

Mr. Nemec said that the joint organization of the United Nations will operate on the basis of a pooling of all means of transport and unifed management of the entire post-war European trankport system for relief purposes. One of the basic assumptions of the Leith Ross Committee was that the aim must ke the full employment of the nations concerned. Mr. Nemec referred briefly to the problems involved in the industrialization of South-Eastern Europe, in which Czechoslovakia might well help; and expressed the view that it is essential to organize import control of important raw materials now, by creating pools for the supply of essential kinds of goods for the post-war relief period and afterwards.

\section{Twenty-One Years of Broadcasting}

NOVEMBER 1943 sees the completion of twenty-one years of regular and authorized broadcasting in Great Britain, and the coming-of-age of the British Broadcasting Corporation-formerly a limited ccmpany with the same initial letters, the British Broadcasting Company, Ltd. The occasion was celebrated by a special programme on Sunday, November 14, during which Mr. John Snagge presented a series of B.B.C. reminiscences. On the following Wednesday, November 17, Mr. Stuart Hiblerd, chief announcer of the B.B.C., read a paper before the Royal Society of Arts entitled "The Coming-of-Age of Broadeasting". The amazing developments which have keen achieved during the growih of broadcasting in Great Britain have been due to the excellent team-work of everybody concerned - artists, programme organizers and enginecrs alike.

Mr. Hibberd stated that it was the general strike of 1926 which brought home to people the importance of broadcasting in a national cmergency, and demonstrated the power of the spoken word. The technical achievements following that include the introduction of the Empire short-wave service in 1927, the broadcasting of the bells of Bethlehem in the Christmas programme of 1933, and of a programme by members of the Byrd Antarctic Expedition from their camp nearly 9,000 miles away in April 1934. These programmes record the attainment of successful collaboration with other organizations such as the Columbia Broadcasting System of America, while one of the greatest triumphs of the outside broadcasting organization was that of the coronation of King George VI, when the whole programme was maintained for six hours non-stop without using a studio at all. During the War, the European and overseas broadcasting services have been developed to the point at which day and night transmissions are now made almost continuously in no less than forty-five foreign languages. In his closing remarks, Mr. Hibberd directed attention to the possibilities of the future; and among these was a plea for a post-war university of the air, by means of which students could be placed in touch with the greatest authorities on their subjects in the land.

Indian Association for the Cultivation of Science

THE annual report of the Indian Association for the Cultivation of Science for the year 1942 includes the presidential address of Sir U. N. Bralmachari, the report of the Committee of Management and a list of papers appearing during the year in the six issues of the Indian Journal of Physics and Proceedings of the Indian Association for the Cultivation of Science. Sir U. N. Brahmachari, referring to tho k eginnings of the Association, quotes from the sketch of the original scheme given by Mahendra Lal Sircar on Decemker 16 , 1875, indicating that the founder had in mind an institution combining the scope, character and object of the Royal Institution in London and the British Association for the Advancement of Science. Dr. Sircar hoped to see it develop into an institution where his countrymen, after finishing their university education, would on their own account carry out original research in the different branches of science. When the scheme had reached maturity, another scheme for a technical institution was launched by the Indian League, and it was only after some controversy that a decision was reached not to amalgamate the schemes, and the Association was inaugurated on July. 29, 1876.

Sir U. N. Brahmachari then discusses the future of the Indian Association, and refers to the proposal to create a new body of members to be called 'fellows' in recognition of distinguished reseurch work conducted by them. The number of life-members has increased by 17 since 1942 and of ordinary memlers by 60 . It was proposed to remove the Institute to a place nearer a seat of scientific learning, to renovate the chemical laboratory and create a fellowship, and ultimately a professorship, in the name of Sir P. C. Ray. The Department of Chemistry proposes to take up the study of some of the more important problems in industrial chemistry, and an approach to the Governments of India and Bengal, the Board of Scientific and Industrial Research and the Rockefeller Foundation might be desirable. In addition to research, however, it is proposed to undertake the propagation of science, for example, by means of a series of lectures by men of the eminence of Sir J. C. Bose, Sir C. V. Raman, Dr. F. W. Aston and others, as well as to continue the present arrangements for research by postgraduate students for the doctorates of various universities. The president also suggested regular meetings for the discussion of scientific subjects by the research workers of the Association, and full co-operation with the University College of Science, Calcutta, the Bose Institute and the science departments of the Colleges afthliated to the University of Calcutta, as well as the Calcutta School of Tropical Medicine and the All India Institute of Hygiene.

\section{Absenteeism among Women}

Emergency RePort No. 4 of the Industrial Health Research Board (H.M. Stationery Office, 1943. 2d.) gives a study of absenteeism among women for the period 1942. It is concerned with the amount and distribution of absenteeism among women rather 